\title{
Severe exacerbations in moderate-to-severe asthmatics are associated with increased pro-inflammatory and type 1 mediators in sputum and serum
}

Michael A. Ghebre ${ }^{1 \dagger}$, Pee Hwee Pang ${ }^{2 \dagger}$, Dhananjay Desai ${ }^{1 \dagger}$, Beverley Hargadon ${ }^{1}$, Chris Newby $^{1}$, Joanne Woods ${ }^{3}$, Laura Rapley ${ }^{3}$, Suzanne E. Cohen ${ }^{3}$, Athula Herath³, Erol A. Gaillard ${ }^{1}$, Richard D. May ${ }^{3,4+}$ and Chris E. Brightling ${ }^{1 *+}$

\begin{abstract}
Background: Asthma is a heterogeneous disease and understanding this heterogeneity will enable the realisation of precision medicine. We sought to compare the sputum and serum inflammatory profiles in moderate-to-severe asthma during stable disease and exacerbation events.

Methods: We recruited 102 adults and 34 children with asthma. The adults were assessed at baseline, 3, 6, and 12month follow-up visits. Thirty-seven subjects were assessed at onset of severe exacerbation. Forty sputum mediators and 43 serum mediators were measured. Receiver-operator characteristic (ROC) curves were constructed to identify mediators that distinguish between stable disease and exacerbation events. The strongest discriminating sputum mediators in the adults were validated in the children.

Results: The mediators that were significantly increased at exacerbations versus stable disease and by $\geq 1.5$-fold were sputum IL-1 $\beta$, IL-6, IL-6R, IL-18, CXCL9, CXCL10, CCL5, TNFa, TNF-R1, TNF-R2, and CHTR and serum CXCL11. No mediators decreased $\geq 1.5$-fold at exacerbation. The strongest discriminators of an exacerbation in adults (ROC area under the curve $[A \cup C]$ ) were sputum TNF-R2 0.69 (95\% Cl: 0.60 to 0.78 ) and IL-6R 0.68 (95\% Cl: 0.58 to 0.78 ). Sputum TNF-R2 and IL-6R were also discriminatory in children (ROC AUC 0.85 [95\% Cl: 0.71 to 0.99] and 0.80 [0.64 to 0.96 respectively).

Conclusions: Severe asthma exacerbations are associated with increased pro-inflammatory and Type 1 (T1) immune mediators. In adults, sputum TNF-R2 and IL-6R were the strongest discriminators of an exacerbation, which were verified in children.
\end{abstract}

Keywords: Asthma, Cytokines, Sputum, Biomarkers

\section{Background}

Asthma affects over 300 million people worldwide. Severe asthma represents about $10 \%$ of all asthmatics [1]. This group has the greatest unmet need with persistent symptoms, airflow obstruction, and chronic inflammation

\footnotetext{
* Correspondence: ceb17@leicester.ac.uk; ceb17@le.ac.uk

${ }^{\dagger}$ Richard D May and Chris E Brightling are co-last authors.

${ }^{+}$Michael A Ghebre, Pee Hwee Pang and Dhananjay Desai are co-first authors.

${ }^{1}$ Institute for Lung Health NIHR Leicester Biomedical Research Centre Department of Respiratory Sciences, University of Leicester and University Hospitals of Leicester NHS Trust, Leicester LE3 9QP, UK

Full list of author information is available at the end of the article
}

punctuated by episodes or worsening of symptoms known as exacerbations. There is an increasing recognition that asthma, in particular severe asthma, is a heterogeneous condition with variability in clinical expression of disease, disordered airway physiology, inflammation and frequency of exacerbations [1-4].

Comparisons of cytokine profiles in eosinophilic versus non-eosinophilic and Type $2(\mathrm{~T} 2)^{\text {high }}$ versus $\mathrm{T} 2^{\text {low }}$ asthma and between asthma, chronic obstructive pulmonary disease (COPD) and asthma/COPD overlap have provided insights into potential underlying mechanisms and responses to therapy [5-8]. Indeed this approach

(c) The Author(s). 2019 Open Access This article is distributed under the terms of the Creative Commons Attribution 4.0 International License (http://creativecommons.org/licenses/by/4.0/), which permits unrestricted use, distribution, and reproduction in any medium, provided you give appropriate credit to the original author(s) and the source, provide a link to the Creative Commons license, and indicate if changes were made. The Creative Commons Public Domain Dedication waiver (http://creativecommons.org/publicdomain/zero/1.0/) applies to the data made available in this article, unless otherwise stated. 
has revealed that asthmatics with eosinophilic, $\mathrm{T} 2^{\text {high }}$ disease respond more favourably to corticosteroids [5] and has uncovered non-eosinophilic, $\mathrm{T} 2{ }^{\text {low }}$ asthmatics in which other mechanisms such as exposure to pollutants or persistent infection might play a role.

Approaches to stratify cytokine profiles in stable disease have been applied widely, but to date there are only a few studies that have explored sputum inflammatory mediators at exacerbations in adults [9-13] and children $[14,15]$. These studies have included small numbers of subjects, limited panels or single sputum mediators and focused mostly upon mild-to-moderate disease, which might explain the variable reports of either increased eosinophils or neutrophils, together with increased T1 or T2 cytokines. Thus surprisingly, there is a paucity of data profiling a broad array of sputum inflammatory mediators in stable disease versus severe exacerbations.

We hypothesised that the sputum and serum inflammatory mediator profiles change between stable disease and exacerbation events. To test this hypothesis, we undertook a 1-year prospective study of moderate-to-severe adult asthmatics, assessed at stable visits and at the onset of severe exacerbations. The findings were then validated in children admitted to hospital with acute asthma exacerbations.

\section{Methods}

\section{Subjects}

In this study 102 adults with moderate-to-severe asthma and 34 children with mild-to-severe asthma, according to the Global Initiative for Asthma (GINA) treatment step [16], were recruited from a single centre Glenfield Hospital, University Hospitals of Leicester NHS Trust, Leicester, United Kingdom. The adults were assessed at baseline, 3, 6, and 12-month follow-up visits and at the onset of a severe exacerbation defined as requiring high dose systemic corticosteroids ( $\geq 30 \mathrm{mg}$ a day) for 3 or more days. Some subjects had participated in an earlier cross-sectional study [8]. The mediators that best discriminated between stable state and exacerbations in the adults were validated in children with doctor-diagnosed asthma admitted to hospital (Royal Infirmary, University Hospitals of Leicester NHS Trust, Leicester, United Kingdom) with acute-severe exacerbations or during stable visits. The studies were approved by the local Leicestershire, Northamptonshire and Rutland ethics committee (08/H0406/189). Written informed consent was obtained from each subject or the subject's legal guardian.

\section{Clinical assessments}

Demographic, clinical and lung function data were recorded including Asthma Control Questionnaire-6 (ACQ6) score, Asthma Quality of Life Questionnaire
(AQLQ) score, symptom scores using the visual analogue scale (VAS), pre- and post-bronchodilator forced expiratory volume in the first second $\left(\mathrm{FEV}_{1}\right)$, forced vital capacity (FVC), fraction of exhaled nitric oxide (FeNO), sputum total and differential cell counts. For the paediatric group only demographics, clinical history and sputum collection was undertaken. Spontaneous sputum was collected at exacerbations and sputum was either spontaneous or induced at stable state dependent on whether subjects produced adequate sputum spontaneously.

\section{Sputum and blood mediator measurements}

Forty mediators in sputum supernatants, and 43 mediators in serum were measured using the Meso Scale Discovery Platform (MSD ${ }^{\circ}$ Gaithersburg, MD, USA) and enzyme-linked immunosorbent assay (ELISA) as described previously [8]. MSD is an immunoassay that combines electrochemiluminescence in a multi-array platform. The lower limits of detection and quantification were reported in the Additional file 1: Table S1. Samples in which mediator concentrations were below half of the limit of quantification (BLQ) were assigned half the limit of quantification. Mediators that were BLQ in more than $60 \%$ of samples were assigned BLQ as a group. The groups that were assigned BLQ were not included in further analyses. These were IL-4, IL-9, IL-10, IL-12p70, IL-13, IL-17, IL-23, IL-33, GMCSF, IFNy, TSLP, NGF and CEACAM-5. Serum IL-6R, CCL3, CCL5 and CCL13 were above the limit of quantification (ALQ) in all the samples and were therefore excluded from further analysis. Seventeen of the serum mediators included in the analysis had $<5 \%$ of the samples outside the measurable range and 5 (IL-1 $\beta$, CCL2, TNF $\alpha$, VEGF, periostin) had $5-20 \%$ of the samples outside of the measurable range. Sixteen of the sputum mediators included in the analysis had $<5 \%$ of the samples outside the measurable range and 10 (IL2, IL5, IL15, IL18, CCL3, CCL4, CCL5, CCL11, CXCL11 and TNFa) had $5-30 \%$ of the samples outside of the measurable range.

\section{Statistical analysis}

All analyses were done with STATA/IC version 14.0 for Windows (Stata Corp, College Station, TX, USA) and Prism version 7.00 for Mac OS X (GraphPad Software, La Jolla California, USA). The parametric and $\log$ transformed data were presented as mean with Standard Error of the Mean (SEM) and geometric mean with $95 \%$ confidence interval (CI) respectively. The changes of characteristics within and between subjects were examined using paired and unpaired t-tests. Receiver operating characteristic (ROC) curves were used to identify the inflammatory mediators that significantly discriminated between stable 
versus exacerbation state for adults. The mediators that best discriminated between stable state and exacerbations in the adults were validated in the stable state versus exacerbation paediatric groups. No corrections were made for multiple comparisons. $P<0.05$ was the threshold for significance.

\section{Results}

The study flow chart is shown in Fig. 1. A total of 102 adult subjects were recruited, of which 37 subjects were assessed at one or more exacerbation visits. The clinical characteristics at baseline of all the subjects and those that were or were not assessed at an exacerbation are described in Table 1. Subjects that had an exacerbation visit had a higher body mass index (BMI) and a higher proportion of severe asthma (Step 5 according to the GINA guidelines). However, there were no significant differences in the ACQ6 score, AQLQ score, daily inhaled and oral corticosteroid dose between the two groups. The proportion of current or ex-smokers was lower in those subjects assessed at exacerbation visits. At exacerbation, there was a significant decrease in $\mathrm{FEV}_{1}$ and an increase in VAS cough, dyspnoea and wheeze. No significant difference was observed in blood and sputum eosinophil and neutrophil cell counts, although sputum total cell count increased significantly at exacerbation (Table 1). The clinical characteristics of the 35 children recruited with an acute-severe exacerbation $(n=18)$ or during a stable visit $(n=17)$ are as shown (Additional file 1: Table S2).

Forty-four sputum and 52 serum samples were obtained from all the exacerbation visits, and 187 sputum and 228 serum samples were also obtained from all the stable visits. In the comparison between all stable and all exacerbation visits (Table 2), sputum IL-1 $\beta$, IL-2, IL-6, IL-6R, IL-18, CXCL9, CXCL10, CCL5, TNF $\alpha$, TNF-R1, TNF-R2, CHTR, and serum IL-18, CXCL10 and CXCL11 were significantly increased at exacerbations.

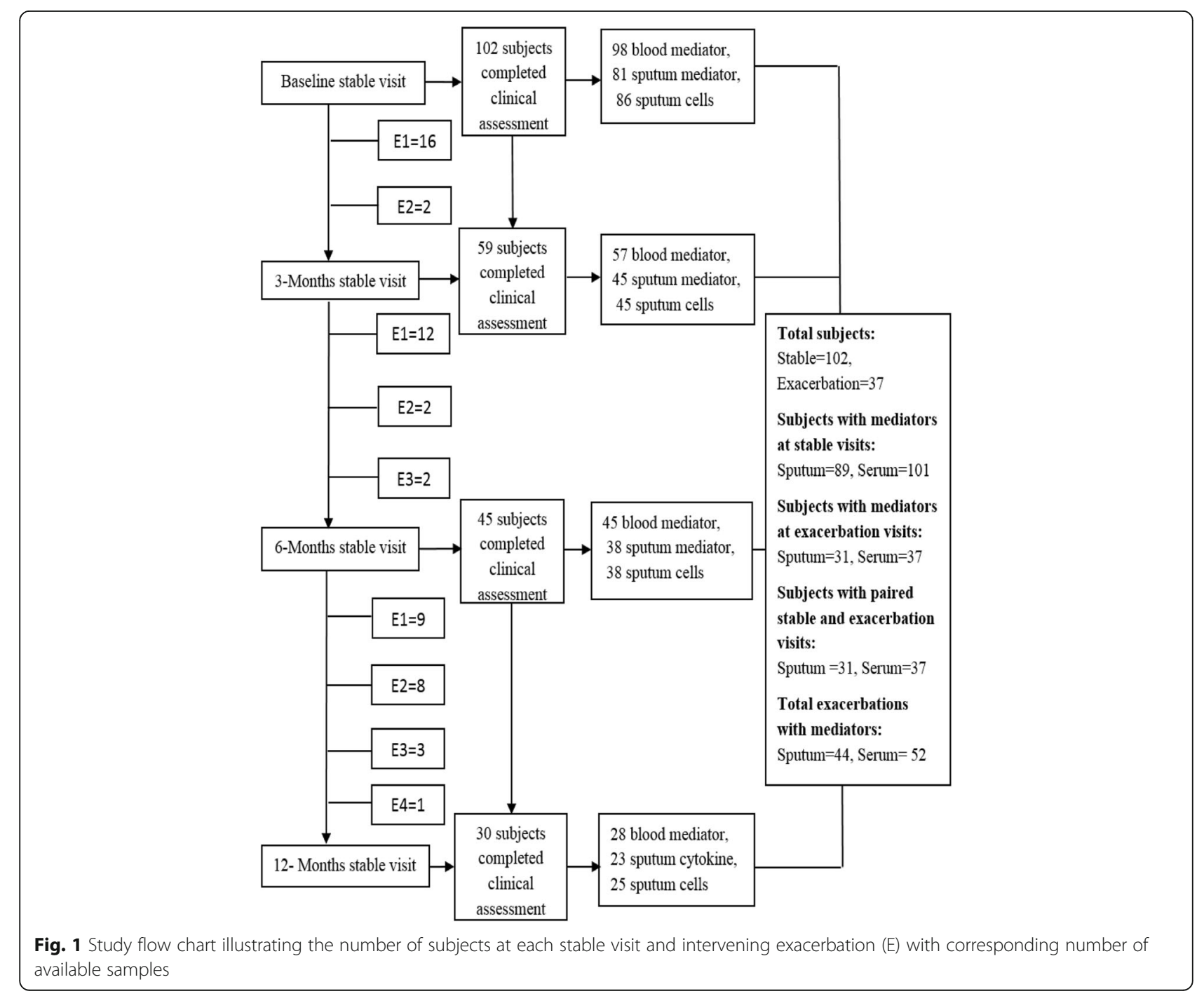




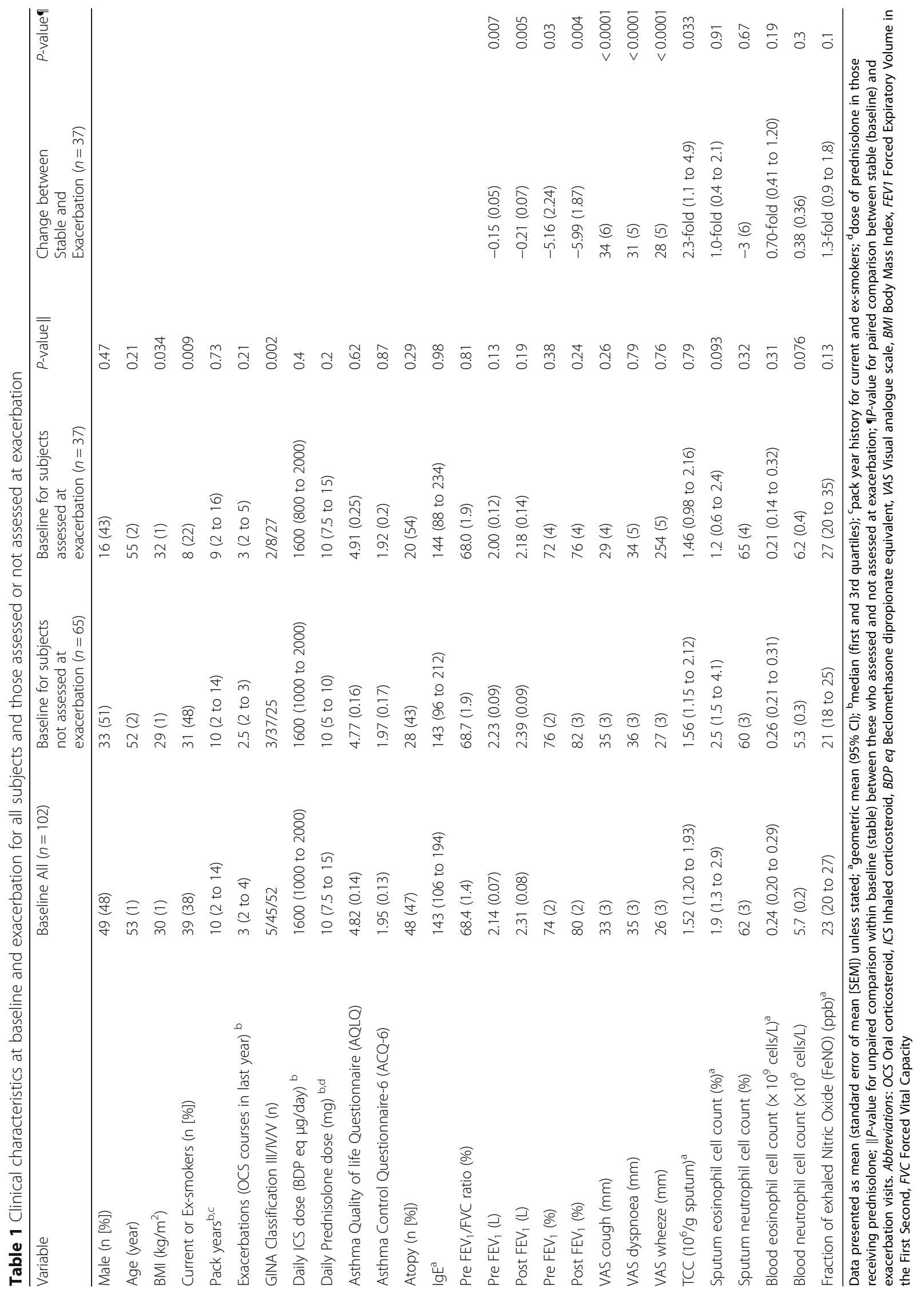


Table 2 Geometric mean $(95 \% \mathrm{Cl})$ sputum and serum mediator concentration (pg/ml) for all stable and all exacerbation vissits

\begin{tabular}{|c|c|c|c|c|c|c|}
\hline & \multicolumn{3}{|l|}{ Sputum } & \multicolumn{3}{|l|}{ Serum } \\
\hline & Stable $(n=187)$ & Exacerbation $(n=44)$ & $P$-value & Stable $(n=228)$ & Exacerbation $(n=52)$ & $P$-value \\
\hline IL-1a & 48 (40 to 57$)$ & 50 (29 to 87$)$ & 0.85 & BLQ & BLQ & \\
\hline $\mathrm{IL}-1 \beta$ & 59 (47 to 74$)$ & 130 (66 to 253 ) & $0.01 \uparrow$ & 3.6 (3.1 to 4.1 ) & 2.8 (2.1 to 3.8$)$ & 0.13 \\
\hline $\mathrm{IL}-2$ & 0.7 (0.6 to 0.8$)$ & 1.1 (0.6 to 1.9$)$ & $0.02 \uparrow$ & BLQ & BLQ & \\
\hline IL-5 & 2.5 (1.9 to 3.2 ) & 2.5 (1.5 to 4.1$)$ & 0.99 & 4.3 (3.8 to 4.9 ) & 4.2 (3.2 to 5.5$)$ & 0.89 \\
\hline IL-6 & 31 (25 to 40 ) & 69 (39 to 123) & $0.01 \uparrow$ & BLQ & BLQ & \\
\hline IL-6R & 195 (169 to 226) & 402 (280 to 577 ) & $<0.0001 \uparrow$ & ALQ & ALQ & \\
\hline IL-8 & 2825 (2295 to 3479) & 4507 (3045 to 6671) & 0.05 & 14 (13 to 15$)$ & 13 (11 to 16$)$ & 0.62 \\
\hline IL-15 & 1.6 (1.3 to 1.9$)$ & 2.3 (1.5 to 3.5$)$ & 0.05 & BLQ & BLQ & \\
\hline IL-18 & 25 (22 to 29$)$ & 48 (30 to 76$)$ & $0.001 \uparrow$ & 323 (304 to 344) & 379 (340 to 422 ) & $0.02 \uparrow$ \\
\hline CXCL9 & 526 (406 to 681) & 1432 (801 to 2558) & $0.001 \uparrow$ & 68 (62 to 75$)$ & 82 (66 to 102$)$ & 0.081 \\
\hline CXCL10 & 632 (506 to 788 ) & 1220 (723 to 2056) & $0.01 \uparrow$ & 120 (112 to 129$)$ & 159 (130 to 195$)$ & $0.002 \uparrow$ \\
\hline CXCL11 & 39 (30 to 51$)$ & $62(27$ to 140$)$ & 0.17 & 135 (125 to 146$)$ & 202 (161 to 252 ) & $<0.0001 \uparrow$ \\
\hline CCL2 & 262 (225 to 305) & 375 (258 to 544$)$ & 0.05 & 621 (590 to 653) & 567 (509 to 633) & 0.13 \\
\hline CCL3 & 27.7 (23.0 to 33.3) & 27.3 (16.8 to 44.2$)$ & 0.95 & ALQ & ALQ & \\
\hline CCL4 & 369 (288 to 473) & 574 (328 to 1004) & 0.13 & 192 (179 to 206) & 179 (153 to 211$)$ & 0.42 \\
\hline CCL5 & 6.6 (5.7 to 7.8 ) & 16.3 (9.9 to 26.7 ) & $<0.0001 \uparrow$ & ALQ & ALQ & \\
\hline CCL11 & 48 (41 to 57 ) & 41 (29 to 59) & 0.44 & 792 (739 to 848 ) & 785 (668 to 923) & 0.92 \\
\hline CCL13 & 18 (15 to 20$)$ & 14 (11 to 19$)$ & 0.19 & ALQ & ALQ & \\
\hline CCL17 & 30 (25 to 36$)$ & 21 (15 to 31$)$ & 0.12 & 587 (513 to 672 ) & 582 (455 to 746 ) & 0.96 \\
\hline CCL26 & 8.6 (6.9 to 11.0 ) & 8.7 (5.5 to 14$)$ & 0.95 & $12.4(10.5$ to 14.8$)$ & 15.4 (10.0 to 23.7$)$ & 0.31 \\
\hline TNFa & 2.5 (2.0 to 3.2 ) & 9.6 (4.3 to 21.3 ) & $<0.0001 \uparrow$ & 5.1 (4.4 to 5.8$)$ & 5.3 (4.0 to 6.9$)$ & 0.78 \\
\hline TNF-R1 & 424 (360 to 500) & 817 (531 to 1255) & $0.001 \uparrow$ & 4044 (3850 to 4247) & 4004 (3677 to 4360 ) & 0.86 \\
\hline TNF-R2 & 200 (164 to 243) & 579 (355 to 943) & $<0.0001 \uparrow$ & 5407 (5122 to 5708$)$ & 5498 (4886 to 6187) & 0.79 \\
\hline VEGF & $1282(1161$ to 1417$)$ & 1289 (1006 to 1651$)$ & 0.97 & 767 (690 to 853 ) & 730 (569 to 929) & 0.67 \\
\hline EGF & 424 (371 to 485 ) & 418 (332 to 528) & 0.92 & 487 (439 to 541 ) & 387 (276 to 543 ) & 0.088 \\
\hline SCF & BLQ & BLQ & & 90 (84 to 97 ) & 92 (80 to 105$)$ & 0.83 \\
\hline ST2 & BLQ & BLQ & & 85.7 (77.4 to 94.9$)$ & 105 (83 to 134$)$ & 0.086 \\
\hline CHTR & $71,358(54,991$ to 92,597$)$ & $191,549(102,748$ to 357,100$)$ & $0.001 \uparrow$ & $132,039(114,285$ to 152,550$)$ & $118,860(90,839$ to 155,523$)$ & 0.54 \\
\hline Periostin & Not done & Not done & & 5.7 (5.3 to 6.2) & 4.7 (3.9 to 5.7$)$ & $0.044 \downarrow$ \\
\hline DDP4 & Not done & Not done & & 449.5 (433.0 to 466.6$)$ & 418.3 (384.0 to 455.7$)$ & 0.11 \\
\hline
\end{tabular}

BLQ Below limit of quantification, ALQ Above limit of quantification, unit of the mediators is $\mathrm{pg} / \mathrm{ml}$, $\uparrow$ increase in mediator concentration, $\downarrow$ decrease in mediator concentration

All entries in bold are significant

Many T2 cytokines (IL-4, IL-9, IL-13, IL-33, TSLP) were below the limit of quantitation both at stable and exacerbation. Serum periostin was significantly decreased at exacerbation compared to stable visits. The difference between stable and exacerbation visits was less than 1.5 fold for sputum IL-2, serum IL-18, CXCL10 and periostin.

The ROC AUC for sputum and serum mediators between all stable and all exacerbation visits are shown in Table 3. The strongest discriminators of an exacerbation in adults were sputum TNF-R2 and IL-6R, with ROC AUC of 0.69 (95\% CI: 0.60 to 0.78 ) and 0.68 (95\% CI:
0.58 to 0.78 ), respectively (Fig. 2a). The results were similar in the paediatric group. The ROC AUC of sputum TNF-R2 and IL-6R in children were 0.85 (95\% CI: 0.71 to 0.99 ) and 0.80 (95\% CI: 0.64 to 0.96 ), respectively (Fig. 2b). In the serum, the best discriminator of an exacerbation was CXCL11, with ROC AUC of 0.66 (95\% CI: 0.57 to 0.76$)$ in adults.

Unpaired and paired comparisons of sputum and serum mediator concentrations for all first stable and first exacerbation visits are shown in Additional file 1: Tables S3 and S4, respectively. The ROC AUC for sputum and serum mediators between all first stable and 
Table 3 ROC AUC (95\% Cl) for sputum and serum mediators between all stable and all exacerbation visits

\begin{tabular}{|c|c|c|}
\hline & $\begin{array}{l}\text { Sputum } \\
(\text { Stable }=187 ; \text { Exacerbation }=44)\end{array}$ & $\begin{array}{l}\text { Serum } \\
(\text { Stable }=228 ; \text { Exacerbation }=52)\end{array}$ \\
\hline IL-1a & 0.50 (0.39 to 0.62 ) & BLQ \\
\hline $\mathrm{IL}-1 \beta$ & 0.59 (0.49 to 0.70$)$ & $0.43(0.35$ to 0.51$)$ \\
\hline $\mathrm{IL}-2$ & 0.57 (0.47 to 0.68$)$ & BLQ \\
\hline $\mathrm{IL}-5$ & 0.50 (0.41 to 0.60$)$ & 0.49 (0.49 to 0.50$)$ \\
\hline IL-6 & $0.61(0.52$ to 0.71$)$ & BLQ \\
\hline IL-6R & $0.68(0.58$ to 0.78$)$ & ALQ \\
\hline IL-8 & 0.59 (0.50 to 0.68$)$ & 0.50 (0.40 to 0.59$)$ \\
\hline IL-15 & 0.59 (0.48 to 0.69$)$ & BLQ \\
\hline IL-18 & $0.62(0.52$ to 0.72$)$ & 0.60 (0.52 to 0.69$)$ \\
\hline CXCL9 & $0.65(0.55$ to 0.74$)$ & $0.60(0.51$ to 0.69$)$ \\
\hline CXCL10 & 0.60 (0.50 to 0.70$)$ & $0.61(0.52$ to 0.70$)$ \\
\hline CXCL11 & 0.53 (0.43 to 0.64$)$ & $0.66(0.57$ to 0.76$)$ \\
\hline CCL2 & 0.57 (0.47 to 0.67 ) & 0.44 (0.35 to 0.54$)$ \\
\hline CCL3 & 0.49 (0.38 to 0.59$)$ & BLQ \\
\hline CCL4 & 0.57 (0.47 to 0.67 ) & 0.48 (0.39 to 0.57$)$ \\
\hline CCL5 & $0.67(0.56$ to 0.77$)$ & ALQ \\
\hline CCL11 & 0.45 (0.36 to 0.55$)$ & 0.50 (0.41 to 0.60$)$ \\
\hline CCL13 & 0.44 (0.36 to 0.52 ) & ALQ \\
\hline CCL17 & 0.42 (0.33 to 0.51$)$ & 0.52 (0.43 to 0.60$)$ \\
\hline CCL26 & 0.50 (0.41 to 0.59$)$ & 0.52 (0.42 to 0.62 ) \\
\hline TNFa & $0.64(0.54$ to 0.74$)$ & 0.52 (0.43 to 0.61$)$ \\
\hline TNF-R1 & $0.63(0.53$ to 0.73$)$ & 0.50 (0.41 to 0.59$)$ \\
\hline TNF-R2 & $0.69(0.60$ to 0.78$)$ & BLQ \\
\hline VEGF & 0.51 (0.41 to 0.62 ) & 0.49 (0.40 to 0.58$)$ \\
\hline EGF & 0.50 (0.40 to 0.59$)$ & 0.46 (0.36 to 0.55$)$ \\
\hline SCF & BLQ & 0.52 (0.44 to 0.60$)$ \\
\hline $\mathrm{ST} 2$ & BLQ & 0.56 (0.47 to 0.66$)$ \\
\hline CHTR & $0.64(0.53$ to 0.74$)$ & 0.46 (0.36 to 0.55$)$ \\
\hline Periostin & Not done & 0.52 (0.46 to 0.58$)$ \\
\hline DDP4 & Not done & 0.41 (0.32 to 0.50$)$ \\
\hline
\end{tabular}

BLQ Below limit of quantification, ALQ Above limit of quantification, unit of the mediators is $\mathrm{pg} / \mathrm{ml}$

All entries in bold are significant

first exacerbations are presented in the Additional file 1: Table S5.

\section{Discussion}

In this study, we report the sputum and serum mediator profiles in moderate-to-severe asthmatics at stable and exacerbation visits. The results showed an increase in $\mathrm{T} 1$ and pro-inflammatory mediators at severe asthma exacerbations. Interestingly, there was no discernible increase in T2 mediators and, in contrast, some T2 mediators such as periostin decreased at exacerbation. From our findings, the strongest discriminators of an exacerbation were TNF-R2 and IL-6R in sputum and CXCL11 in serum. Similarly, in the paediatric group sputum TNF-R2 and IL-6R discriminated between stable and exacerbation events. Taking our findings together, up-regulated $\mathrm{T} 1$ and pro-inflammatory mediators rather than T2 inflammation appear to characterise severe asthma exacerbations.

TNF $\alpha$ is an important cytokine in the innate immune system, which is synthesized as a transmembrane precursor protein, mainly by activated macrophages and $\mathrm{T}$ cells. The cytoplasmic tail of this protein is then cleaved to release soluble TNF $\alpha$. An aggregation of three TNF $\alpha$ monomers is required to form the trimeric TNF $\alpha$, which then binds to ubiquitously expressed transmembrane 


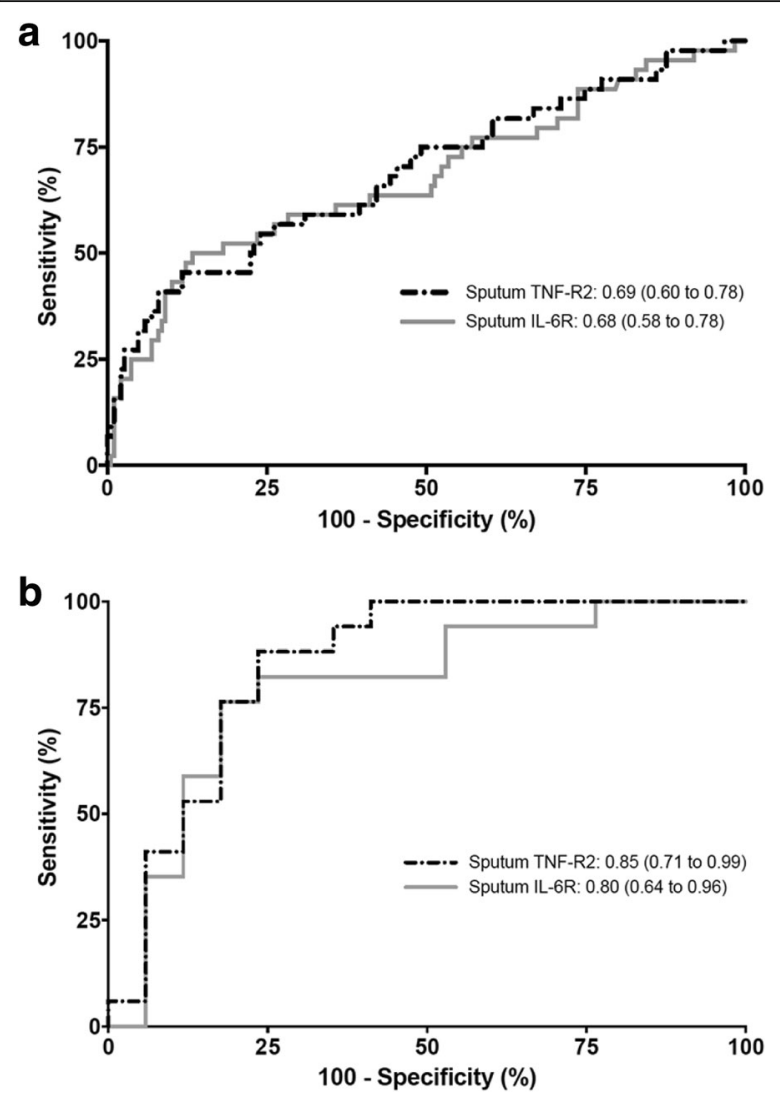

Fig. 2 Sputum IL-6R and TNF-R2 ROC curves in adults (a) and children (b)

receptors, TNF-R1 and TNF-R2. This in turn stimulates the release of various pro-inflammatory cytokines such as IL-1 $\beta$, IL- 6 and IL-8. TNF $\alpha$ has been implicated in asthma, with up-regulation of the TNF $\alpha$ axis noted in patients with severe refractory asthma [17-19]. However, in spite of early efficacy late phase trials of anti-TNF $\alpha$ therapy in asthma failed to demonstrate important benefits and were discontinued early due to more frequent infections and higher incidence of malignancies in the treatment group [20]. Soluble TNF-R1 and TNF-R2 are formed by the proteolytic cleavage of the extracellular domains of the TNF $\alpha$ receptors. These soluble TNF $\alpha$ receptors can act as antagonists and function as natural regulators of the TNF $\alpha$ activity, thus diminishing the pro-inflammatory effects of TNF $\alpha$. In our study, both TNF $\alpha$ and soluble TNF $\alpha$ receptors are significantly upregulated at exacerbation compared to stable visits. In this regard, IL-6R then emerges as potentially more important than TNF $\alpha$ and its soluble receptors.

There is emerging evidence implicating IL- 6 and its receptor in the pathogenesis of asthma. Elevated levels of IL-6 had been found in serum [21], induced sputum [22], bronchoalveolar fluid [23] and lung tissues of asthmatic patients [24]. Asthmatic patients with high serum IL-6 were found to have significantly worse lung function and more frequent exacerbations [25, 26]. A large Australian genome-wide association study identified a single-nucleotide polymorphism (SNP) located in the IL-6R gene (rs4129267) to be associated with asthma risk [27]. Soluble IL-6R was also found to be elevated in serum and bronchoalveolar fluid of asthmatic patients after allergen challenge and during spontaneous exacerbation $[28,29]$. There are two signalling pathways driven by IL-6. IL-6 binds to membrane-bound IL-6R (mIL-6R) found on leukocytes and hepatocytes, before associating with the gp130 glycoprotein, to trigger the intracellular signalling cascades. The trans-signalling pathway is via the soluble IL-6R (sIL-6R), which is formed by the proteolytic cleavage of the mIL-6R or the translation from alternatively spliced messenger RNA (mRNA). The IL-6/sIL-6R complex then binds to gp130 glycoprotein, which is ubiquitously expressed. Thus, in contrast to soluble TNF-R1 and 2 , which antagonise the effect of TNF $\alpha$, soluble IL-6R can amplify the effects of IL- 6 as it permits IL- 6 to stimulate cells even if they lack mIL-6R. The IL-6R coding SNP rs2228145 ( $\mathrm{Asp}^{358} \mathrm{Ala}$ ), which increases IL-6R shedding and promotes IL-6 trans-signalling is associated with lower predicted $\mathrm{FEV}_{1}$ [30] and is more frequent in the severe asthma clusters in the Severe Asthma Research Program (SARP) cohort. This suggests that IL-6 trans-signalling may have a key role in asthma severity. IL-6 transsignalling has also been implicated in other diseases such as chronic inflammatory bowel disease and colon cancer [31], with a humanized monoclonal IL-6R antibody (tocilizumab) currently licensed for use in rheumatoid arthritis and systemic juvenile idiopathic arthritis [32]. IL-6 production is also linked to obesity [33]. The BMI was increased in those adult subjects that had an exacerbation versus the whole adult group whereas in contrast the BMI was lower in the exacerbation versus stable group for the children studied. In our study the increase in IL6R could not be attributed to BMI alone. Whether sputum IL-6R at exacerbations represents a target for asthma therapy or is a consequence of infection highlighting the possible need for anti-microbial therapy in some asthmatics at exacerbations is uncertain, although antibiotics have not consistently demonstrated improved outcomes for severe asthma exacerbations [34].

The interferon- $\gamma$-induced chemokines CXCL9, 10 and 11 were increased in either or both sputum and serum at exacerbations versus stable disease. These chemokines especially serum CXCL10 are increased in asthma and COPD exacerbations triggered by rhinoviral infections $[6,35,36]$. It is therefore likely that some of the exacerbation events in our study were triggered by viral infections. Both $\mathrm{T} 1$ and $\mathrm{T} 2$ responses have been reported following viral infections $[9,35,37-39]$. However, in our study there were no increases in T2 mediators. Although 
a number of T2 mediators (IL-4, IL-9, IL-13, IL-33, TSLP) were below half of the limit of quantitation at both stable and exacerbation states, the T2 mediator periostin decreased at exacerbation versus stable state. Taken together our findings are consistent with infection rather than perturbed T2 immunity e.g. allergic responses as an important trigger for exacerbations. Despite this, drugs targeting T2-mediated inflammation such as anti-IL-5/IL-5 receptor monoclonal antibodies are proven to reduce exacerbations in severe eosinophilic asthma [40-42]. Drugs targeting the T2 cytokines IL-4 and IL-13 also appear to play a role in reducing exacerbations in patients with severe asthma [43-45]. It remains to be determined from ongoing phase III clinical trials to what extent patient sub-groups, which specifically express elevated biomarkers indicative of IL-13 signalling, will benefit from these treatments. Our data suggest that targeting underlying T2-mediated inflammation and thereby reducing susceptibility to exacerbations may be a more likely mechanism of action than direct targeting of exacerbation triggers themselves.

There are several potential limitations in this study. We prospectively studied asthma subjects that had a good success rate of producing adequate sputum for cell differential and cytokine analysis. This could have introduced an acquisition bias towards an infective phenotype, although we did not systematically assess the aetiology of the exacerbation. Notwithstanding this limitation, our success rate as a single centre to obtain adequate sputum samples for analysis is very high. Salivary contamination can affect the interpretation of sputum mediators. However, this is minimised using standardised sputum plug selection methods. Thus, this bias is unlikely to have had a major impact on our findings. We did not record asthma age of onset which might have affected the mediator profiles. Although we undertook a relatively large study of severe asthma exacerbations compared to reported studies [9-15], the study size is modest; undertaken in a single-centre and no corrections for multiple comparisons were made. The sample size limits our ability to explore asthma subgroups using statistical techniques such as cluster analysis, which we have applied to similar datasets in COPD [6]. Importantly, we were able to examine an extensive panel of mediators in both sputum and serum samples, which allowed us to explore effects upon T1 versus T2 immunity. However, we acknowledge a need for more sensitive assays of T2 mediators especially as our groups studied did not have high levels of T2 mediators either due to the sensitivity of the assays, recruitment of a predominately T2 low group or as a consequence of corticosteroid therapy. Some of the mediators were outside the measurable range which reduces the precision of these analyses. However, the most discriminatory biomarkers namely sputum IL6R and TNFR2 were measurable in all samples. Additionally we replicated our findings in children recruited either at stale visits or at exacerbations. Although data derived from children and adults are not directly comparable the generalisability of our findings in the different age groups suggests they are not restricted to adults. Larger, multi-centre prospective studies to examine the inflammatory profiles of asthma exacerbations in adults and children are required in the future.

\section{Conclusions}

In conclusion, we found in moderate-to-severe asthmatics that the $\mathrm{T} 1$ and pro-inflammatory mediators in sputum and serum were up-regulated at exacerbation without a significant T2 response. Sputum TNF-R2 and IL-6R were strongly associated with asthma exacerbations in both adults and children. Our findings suggest that the role of the IL-6/IL-6R axis in asthma exacerbations warrants further investigation.

\section{Additional files}

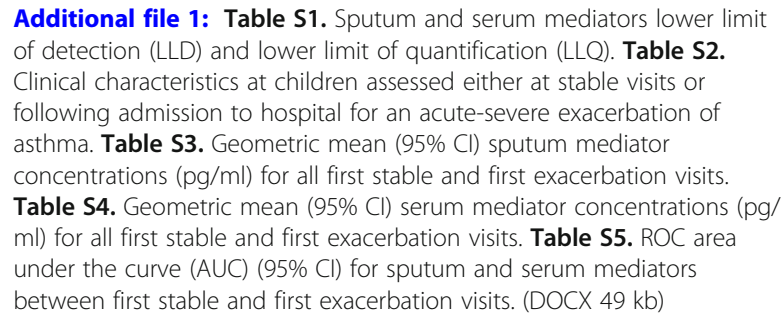

Additional file 1: Table S1. Sputum and serum mediators lower limit of detection (LLD) and lower limit of quantification (LLQ). Table S2. Clinical characteristics at children assessed either at stable visits or following admission to hospital for an acute-severe exacerbation of asthma. Table S3. Geometric mean ( $95 \%$ Cl) sputum mediator concentrations $(\mathrm{pg} / \mathrm{ml})$ for all first stable and first exacerbation visits. Table S4. Geometric mean $(95 \% \mathrm{Cl}$ ) serum mediator concentrations (pg/ $\mathrm{ml}$ ) for all first stable and first exacerbation visits. Table S5. ROC area under the curve (AUC) $(95 \% \mathrm{Cl}$ ) for sputum and serum mediators between first stable and first exacerbation visits. (DOCX $49 \mathrm{~kb}$ )

\section{Abbreviations}

ACQ6: Asthma Control Questionnaire-6; ALQ: Above the limit of quantification; AQLQ: Asthma Quality of Life Questionnaire; AUC: Area under the curve; BLQ: Below half of the limit of quantification; BMI: Body mass index; Cl: Confidence interval; COPD: Chronic obstructive pulmonary disease; ELISA: Enzyme-linked immunosorbent assay; FeNO: Fraction of exhaled nitric oxide; $F_{1}$ : Forced expiratory volume in the first second; FVC: Forced vital capacity; GINA: Global Initiative for Asthma; mRNA: Messenger RNA; ROC: Receiver-operator characteristic; SARP: Severe Asthma Research Program; SEM: Standard Error of the Mean; SNP: Single-nucleotide polymorphism; T1: Type 1; T2: Type 2; VAS: Visual analogue scale

\section{Acknowledgements}

Not applicable.

\section{Authors' contributions}

MAG undertook the data analysis, statistical analysis and involved in manuscript writing. PHP involved in data analysis and manuscript writing DD undertook the volunteer recruitment, data collection, and involved in data analysis and manuscript writing. $\mathrm{BH}$ involved in data collection and manuscript writing; $\mathrm{CN}, \mathrm{SC}$ and $\mathrm{AH}$ involved in data analysis, statistical analysis and manuscript writing. JW and LR involved in analysing samples and manuscript writing. EG involved in data collection, volunteer recruitment, data analysis, and manuscript writing. RM and CEB led the design of the study, data collection, data interpretation, data analyses and had full access to the data and are responsible for the integrity of the data and final decision to submit. All authors contributed to the study design, writing of the manuscript and have approved the final version for submission. 


\section{Funding}

Medlmmune Ltd., Wellcome Trust Senior Fellowship (CEB). The research was performed in laboratories part funded by the European Regional Development Fund (ERDF 05567). This study was also part supported by the National Institute for Health Research Leicester Biomedical Research Centre, UK, and AirPROM (FP7-270194). The views expressed are those of the author(s) and not necessarily those of the NHS, the NIHR or the Department of Health.

\section{Availability of data and materials}

The data that support the findings of this study are available from the corresponding author upon reasonable request.

\section{Ethics approval and consent to participate}

The studies were approved by the local Leicestershire, Northamptonshire and Rutland ethics committee. Written informed consent was obtained from each subject or the subject's legal guardian.

\section{Consent for publication}

Each subject or legal guardian provided written informed consent to analyze and publish his/her data.

\section{Competing interests}

The authors declare that they have no competing interests.

\section{Author details}

${ }^{1}$ Institute for Lung Health NIHR Leicester Biomedical Research Centre Department of Respiratory Sciences, University of Leicester and University Hospitals of Leicester NHS Trust, Leicester LE3 9QP, UK. ${ }^{2}$ Department of Respiratory and Critical Care Medicine, Tan Tock Seng Hospital, Singapore, Singapore. ${ }^{3}$ Medlmmune Ltd, Milstein Building, Granta Park, Cambridge CB21 6GH, UK. ${ }^{4}$ Present address: Camallergy, Cambridge Biomedical Campus, Cambridge, UK.

Received: 22 May 2018 Accepted: 26 July 2019

Published online: 08 August 2019

\section{References}

1. Chung KF, Wenzel SE, Brozek JL, Bush A, Castro M, Sterk PJ, Adcock IM, Bateman ED, Bel EH, Bleecker ER, Boulet LP, Brightling C, Chanez P, Dahlen SE, Djukanovic R, Frey U, Gaga M, Gibson P, Hamid Q, Jajour NN, Mauad T, Sorkness RL, Teague WG. International ERS/ATS guidelines on definition, evaluation and treatment of severe asthma. Eur Respir J. 2014;43(2):343-73.

2. Hartley R, Berair R, Brightling CE. Severe asthma: novel advances in the pathogenesis and therapy. Pol Arch Med Wewn. 2014;124(5):247-54.

3. Haldar P, Pavord ID, Shaw DE, Berry MA, Thomas M, Brightling CE, Wardlaw AJ, Green RH. Cluster analysis and clinical asthma phenotypes. Am J Respir Crit Care Med. 2008;178(3):218-24.

4. Wu W, Bleecker E, Moore W, Busse WW, Castro M, Chung KF, Calhoun WJ, Erzurum S, Gaston B, Israel E, Curran-Everett D, Wenzel SE. Unsupervised phenotyping of severe Asthma research program participants using expanded lung data. J Allergy Clin Immunol. 2014;133(5):1280-8.

5. Woodruff PG, Modrek B, Choy DF, Jia G, Abbas AR, Ellwanger A, Koth LL, Arron JR, Fahy JV. T-helper type 2-driven inflammation defines major subphenotypes of asthma. Am J Respir Crit Care Med. 2009;180(5):388-95.

6. Bafadhel M, McKenna S, Terry S, Mistry V, Reid C, Haldar P, McCormick M, Haldar K, Kebadze T, Duvoix A, Lindblad K, Patel H, Rugman P, Dodson P, Jenkins M, Saunders M, Newbold P, Green RH, Venge P, Lomas DA, Barer MR, Johnston SL, Pavord ID, Brightling CE. Acute exacerbations of chronic obstructive pulmonary disease: identification of biologic clusters and their biomarkers. Am J Respir Crit Care Med. 2011;184(6):662-71.

7. Bafadhel M, McCormick M, Saha S, McKenna S, Shelley M, Hargadon B, Mistry V, Reid C, Parker D, Dodson P, Jenkins M, Lloyd A, Rugman P, Newbold P, Brightling CE. Profiling of sputum inflammatory mediators in asthma and chronic obstructive pulmonary disease. Respiration. 2012;83(1): 36-44.

8. Ghebre MA, Bafadhel M, Desai D, Cohen SE, Newbold P, Rapley L, Woods J, Rugman P, Pavord ID, Newby C, Burton PR, May RD, Brightling CE. Biological clustering supports both "Dutch" and "British" hypotheses of asthma and chronic obstructive pulmonary disease. J Allergy Clin Immunol. 2015;135(1):63-72.
9. Pizzichini MM, Pizzichini E, Efthimiadis A, Chauhan AJ, Johnston SL, Hussack P. Mahony J, Dolovich J, Hargreave FE. Asthma and natural colds. Inflammatory indices in induced sputum: a feasibility study. Am J Respir Crit Care Med. 1998;158(4):1178-84.

10. Pizzichini MM, Pizzichini E, Clelland L, Efthimiadis A, Mahony J, Dolovich J, Hargreave FE. Sputum in severe exacerbations of asthma: kinetics of inflammatory indices after prednisone treatment. Am J Respir Crit Care Med. 1997;155(5):1501-8.

11. Fahy JV, Kim KW, Liu J, Boushey HA. Prominent neutrophilic inflammation in sputum from subjects with asthma exacerbation. J Allergy Clin Immunol. 1995;95(4):843-52

12. Daldegan MB, Teixeira MM, Talvani A. Concentration of CCL11, CXCL8 and TNF-alpha in sputum and plasma of patients undergoing asthma or chronic obstructive pulmonary disease exacerbation. Braz I Med Biol Res. 2005;38(9): 1359-65.

13. Warwick G, Thomas PS, Yates DH. Non-invasive biomarkers in exacerbations of obstructive lung disease. Respirology. 2013;18(5):874-84.

14. Norzila MZ, Fakes K, Henry RL, Simpson J, Gibson PG. Interleukin-8 secretion and neutrophil recruitment accompanies induced sputum eosinophil activation in children with acute asthma. Am J Respir Crit Care Med. 2000; $161(3$ Pt 1):769-74.

15. Bosco A, Ehteshami S, Stern DA, Martinez FD. Decreased activation of inflammatory networks during acute asthma exacerbations is associated with chronic airflow obstruction. Mucosal Immunol. 2010;3(4):399-409.

16. www.ginasthma.org. Accessed 2 Aug 2019.

17. Brightling C, Berry M, Amrani Y. Targeting TNF-alpha: a novel therapeutic approach for asthma. J Allergy Clin Immunol. 2008;121(1):5-10 quiz 11-2.

18. Berry MA, Hargadon B, Shelley M, Parker D, Shaw DE, Green RH, Bradding P, Brightling CE, Wardlaw AJ, Pavord ID. Evidence of a role of tumor necrosis factor alpha in refractory asthma. N Engl J Med. 2006;354(7):697-708.

19. Howarth PH, Babu KS, Arshad HS, Lau L, Buckley M, McConnell W, Beckett P, Al Ali M, Chauhan A, Wilson SJ, Reynolds A, Davies DE, Holgate ST. Tumour necrosis factor (TNFalpha) as a novel therapeutic target in symptomatic corticosteroid dependent asthma. Thorax. 2005;60(12):1012-8.

20. Wenzel SE, Barnes PJ, Bleecker ER, Bousquet J, Busse W, Dahlen SE, Holgate ST, Meyers DA, Rabe KF, Antczak A, Baker J, Horvath I, Mark Z, Bernstein D, Kerwin E, Schlenker-Herceg R, Lo KH, Watt R, Barnathan ES, Chanez P, T03 Asthma Investigators. A randomized, double-blind, placebo-controlled study of tumor necrosis factor-alpha blockade in severe persistent asthma. Am J Respir Crit Care Med. 2009;179(7):549-58.

21. Yokoyama A, Kohno N, Fujino S, Hamada H, Inoue Y, Fujioka S, Ishida S, Hiwada K. Circulating interleukin-6 levels in patients with bronchial asthma. Am J Respir Crit Care Med. 1995;151(5):1354-8.

22. Neveu WA, Allard JL, Raymond DM, Bourassa LM, Burns SM, Bunn JY, Irvin CG, Kaminsky DA, Rincon M. Elevation of IL-6 in the allergic asthmatic airway is independent of inflammation but associates with loss of central airway function. Respir Res. 2010;11:28. https://doi.org/10.1186/14659921-11-28.

23. Tillie-Leblond I, Pugin J, Marquette CH, Lamblin C, Saulnier F, Brichet A, Wallaert B, Tonnel AB, Gosset P. Balance between proinflammatory cytokines and their inhibitors in bronchial lavage from patients with status asthmaticus. Am J Respir Crit Care Med. 1999;159(2):487-94.

24. Marini M, Vittori E, Hollemborg J, Mattoli S. Expression of the potent inflammatory cytokines, granulocyte-macrophage-colony-stimulating factor and interleukin-6 and interleukin-8, in bronchial epithelial cells of patients with asthma. J Allergy Clin Immunol. 1992;89(5):1001-9.

25. Peters MC, McGrath KW, Hawkins GA, Hastie AT, Levy BD, Israel E, Phillips BR, Mauger DT, Comhair SA, Erzurum SC, Johansson MW, Jarjour NN, Coverstone AM, Castro M, Holguin F, Wenzel SE, Woodruff PG, Bleecker ER, Fahy JV. National Heart, Lung, and Blood Institute severe Asthma research program: plasma interleukin-6 concentrations, metabolic dysfunction, and asthma severity: a cross-sectional analysis of two cohorts. Lancet Respir Med. 2016;4(7):574-84.

26. Fu JJ, McDonald VM, Baines KJ, Gibson PG. Airway IL-1 beta and Systemic inflammation as predictors of future exacerbation risk in Asthma and COPD. Chest. 2015;148(3):618-29.

27. Ferreira MA, Matheson MC, Duffy DL, Marks GB, Hui J, Le Souef P, Danoy P, Baltic S, Nyholt DR, Jenkins M, Hayden C, Willemsen G, Ang W, Kuokkanen M, Beilby J, Cheah F, de Geus EJ, Ramasamy A, Vedantam S, Salomaa V, Madden PA, Heath AC, Hopper JL, Visscher PM, Musk B, Leeder SR, Jarvelin MR, Pennell C, Boomsma DI, Hirschhorn JN, Walters H, Martin NG, James A, 
Jones G, Abramson MJ, Robertson CF, Dharmage SC, Brown MA, Montgomery GW, Thompson PJ. Australian Asthma genetics consortium: identification of IL6R and chromosome 11q13.5 as risk loci for asthma. Lancet. 2011;378(9795):1006-14

28. Doganci A, Eigenbrod T, Krug N, De Sanctis GT, Hausding M, Erpenbeck VJ, Haddad e LHA, Schmitt E, Bopp T, Kallen KJ, Herz U, Schmitt S, Luft C, Hecht O, Hohlfeld JM, Ito H, Nishimoto N, Yoshizaki K, Kishimoto T, Rose-John S, Renz H, Neurath MF, Galle PR, Finotto S. The IL-6R alpha chain controls lung CD4+CD25+ Treg development and function during allergic airway inflammation in vivo. J Clin Invest. 2005;115(2):313-25.

29. Yokoyama A, Kohno N, Sakai K, Kondo K, Hirasawa Y, Hiwada K. Circulating levels of soluble interleukin-6 receptor in patients with bronchial asthma. Am J Respir Crit Care Med. 1997;156(5):1688-91.

30. Hawkins GA, Robinson MB, Hastie AT, Li X, Li H, Moore WC, Howard TD, Busse WW, Erzurum SC, Wenzel SE, Peters SP, Meyers DA, Bleecker ER. National Heart, Lung, and Blood Institute-sponsored severe Asthma research program (SARP): the IL6R variation asp (358) ala is a potential modifier of lung function in subjects with asthma. J Allergy Clin Immunol. 2012;130(2): 510-5.e1.

31. Rose-John S, Scheller J, Elson G, Jones SA. Interleukin-6 biology is coordinated by membrane-bound and soluble receptors: role in inflammation and cancer. J Leukoc Biol. 2006;80(2):227-36.

32. Singh JA, Beg S, Lopez-Olivo MA. Tocilizumab for rheumatoid arthritis: a Cochrane systematic review. J Rheumatol. 2011;38(1):10-20.

33. Eder K, Baffy N, Falus A, Fulop AK. The major inflammatory mediator interleukin-6 and obesity. Inflamm Res. 2009;58(11):727-36.

34. Johnston SL, Szigeti M, Cross M, Brightling C, Chaudhuri R, Harrison T, Mansur A, Robison L, Sattar Z, Jackson D, Mallia P, Wong E, Corrigan C, Higgins B, Ind P, Singh D, Thomson NC, Ashby D, Chauhan A. AZALEA trial team: azithromycin for acute exacerbations of Asthma : the AZALEA randomized clinical trial. JAMA Intern Med. 2016;176(11):1630-7.

35. Wark PA, Bucchieri F, Johnston SL, Gibson PG, Hamilton L, Mimica J, Zummo G, Holgate ST, Attia J, Thakkinstian A, Davies DE. IFN-gammainduced protein 10 is a novel biomarker of rhinovirus-induced asthma exacerbations. J Allergy Clin Immunol. 2007;120(3):586-93.

36. Quint JK, Donaldson GC, Goldring JJ, Baghai-Ravary R, Hurst JR, Wedzicha JA. Serum IP-10 as a biomarker of human rhinovirus infection at exacerbation of COPD. Chest. 2010;137(4):812-22.

37. Parry DE, Busse WW, Sukow KA, Dick CR, Swenson C, Gern JE. Rhinovirusinduced PBMC responses and outcome of experimental infection in allergic subjects. J Allergy Clin Immunol. 2000;105(4):692-8.

38. Beale J, Jayaraman A, Jackson DJ, Macintyre JD, Edwards MR, Walton RP, Zhu J, Ching YM, Shamji B, Edwards M, Westwick J, Cousins DJ, Hwang YY, McKenzie A, Johnston SL, Bartlett NW. Rhinovirus-induced IL-25 in asthma exacerbation drives type 2 immunity and allergic pulmonary inflammation. Sci Transl Med. 2014;6(256):256ra134.

39. Jackson DJ, Makrinioti H, Rana BM, Shamji BW, Trujillo-Torralbo MB, Footitt J, Jerico D, Telcian AG, Nikonova A, Zhu J, Aniscenko J, Gogsadze L, Bakhsoliani E, Traub S, Dhariwal J, Porter J, Hunt D, Hunt T, Hunt T, Stanciu LA, Khaitov M, Bartlett NW, Edwards MR, Kon OM, Mallia P, Papadopoulos NG, Akdis CA, Westwick J, Edwards MJ, Cousins DJ, Walton RP, Johnston SL. IL-33-dependent type 2 inflammation during rhinovirus-induced asthma exacerbations in vivo. Am J Respir Crit Care Med. 2014;190(12):1373-82.

40. Pavord ID, Korn S, Howarth P, Bleecker ER, Buhl R, Keene ON, Ortega H, Chanez P. Mepolizumab for severe eosinophilic asthma (DREAM): a multicentre, double-blind, placebo-controlled trial. Lancet. 2012;380(9842): 651-9.

41. Bjermer L, Lemiere C, Maspero J, Weiss S, Zangrilli J, Germinaro M Reslizumab for inadequately controlled Asthma with elevated blood eosinophil levels: a randomized phase 3 study. Chest. 2016; 150(4):789-98

42. FitzGerald JM, Bleecker ER, Nair P, Korn S, Ohta K, Lommatzsch M, Ferguson GT, Busse WW, Barker P, Sproule S, Gilmartin G, Werkstrom V, Aurivillius M, Goldman M. CALIMA study investigators: Benralizumab, an anti-interleukin-5 receptor alpha monoclonal antibody, as add-on treatment for patients with severe, uncontrolled, eosinophilic asthma (CALIMA): a randomised, double-blind, placebo-controlled phase 3 trial. Lancet. 2016;388(10056):2128-41.

43. Wenzel S, Castro M, Corren J, Maspero J, Wang L, Zhang B, Pirozzi G, Sutherland ER, Evans RR, Joish VN, Eckert L, Graham NM, Stahl N, Yancopoulos GD, Louis-Tisserand M, Teper A. Dupilumab efficacy and safety in adults with uncontrolled persistent asthma despite use of medium-tohigh-dose inhaled corticosteroids plus a long-acting beta2 agonist: a randomised double-blind placebo-controlled pivotal phase $2 \mathrm{~b}$ dose-ranging trial. Lancet. 2016;388(10039):31-44.

44. Hanania NA, Korenblat P, Chapman KR, Bateman ED, Kopecky P, Paggiaro P, Yokoyama A, Olsson J, Gray S, Holweg CT, Eisner M, Asare C, Fischer SK, Peng K, Putnam WS, Matthews JG. Efficacy and safety of lebrikizumab in patients with uncontrolled asthma (LAVOLTA I and LAVOLTA II): replicate, phase 3, randomised, double-blind, placebo-controlled trials. Lancet Respir Med. 2016:4(10):781-96.

45. Papi A, Brightling C, Pedersen SE, Reddel HK. Asthma. Lancet. 2018; 391(10122):783-800.

\section{Publisher's Note}

Springer Nature remains neutral with regard to jurisdictional claims in published maps and institutional affiliations.
Ready to submit your research? Choose BMC and benefit from:

- fast, convenient online submission

- thorough peer review by experienced researchers in your field

- rapid publication on acceptance

- support for research data, including large and complex data types

- gold Open Access which fosters wider collaboration and increased citations

- maximum visibility for your research: over $100 \mathrm{M}$ website views per year

At BMC, research is always in progress.

Learn more biomedcentral.com/submissions 